\title{
Eger komplex vonzáskörzetének dinamikai vizsgálata
}

\author{
Dynamical analysis of the complex \\ hinterland of Eger
}

BODOR NORBERT, PÉNZES JÁNOS

KULCSSZAVAK: vonzáskörzet-számítás, ingázás, kiskereskedelem, középfokú oktatás

\begin{abstract}
ABSZTRAKT: Tanulmányunkban Eger vonzáskörzetének vizsgálatával foglalkozunk, igyekszünk dinamikai összehasonlítást is végezni egy 1980-as átfogó felmérés eredményeivel. Elemzésünk célja az, hogy Eger négy ágazatra - kiskereskedelem, foglalkoztatás, egészségügy és oktatás - vonatkozó, valamint komplex vonzáskörzetét feltárjuk, és bemutassuk az elmúlt három évtizedben lezajlott változásokat, továbbá ezek magyarázatára is kitérjünk.

Eger kiskereskedelmi vonzáskörzete megváltozott, mivel az ágazat egésze is jelentősen átalakult. A vásárlások száma nőtt, azonban a vidéki vásárlók aránya csökkent. $A$ legnagyobb áruházak nagyobb vonzásövvel rendelkeznek, mint a belvárosi üzletek, ugyanakkor összességében véve Eger vonzáskörzete mégis csökkent. A megyeszékhely foglalkoztatási szerepe nőtt, vonzáskörzete kiterjedt, ez azonban kevesebb Egerbe ingázó munkavállalót jelentett a foglalkoztatás jelentős rendszerváltás utáni leépülése miatt. Az egészségügyi vonzáskörzet adminisztrativ úton szabályozott, és nem változott meg érdemben 1980-hoz képest. A középfokú oktatási vonzáskörzet a tankötelezettség korhatárának emelése miatt minden tekintetben kiterjedt.

Tanulmányunk legfontosabb következtetései a következők. Ágazatonként eltérő tendenciák érvényesültek, amelyek hátterében különböző társadalmi, gazdasági és politikai okok húzódtak meg. A lezajlott változások kettős képet mutatnak, mivel Eger komplex vonzáskörzetének abszolút kiterjedése csökkent, valamint az erősebben vonzott települések köre is szűkült. Ugyanakkor a megyeszékhely közelében fekvő - szuburbanizációs célterületnek számító - települések esetében mégis jellemzően erősödött a vonzás intenzitása.
\end{abstract}

KEYWORDS: sphere of influence, calculation of hinterland, commuting, commerce, secondary education

ABSTRACT: The analysis of Eger's hinterland was based on the investigation of different spheres - commerce, employment, health and education. The analysis received a dynamical character with the comparison to the results of a former study carried out in the 1980s. The objectives of the current study were to illustrate and represent each sphere of influence, the complex hinterland and to discover the main reasons causing changes during the 30 years between 1980 and 2010 under investigation. The

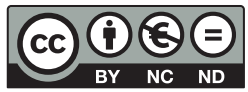


investigation was based on our own collection of data and on the results of a census in 2001.

The introduction provides an overview of the most important interpretations and explanations of the definition of hinterland. The following section represents the methodology applied in the case of Hungarian and some foreign studies. The structure of the study followed the spheres listed and the complex of the hinterland.

The total value of the number of purchases grew in the commercial hinterland, but the ratio of non-local customers decreased. The database indicates a more extended sphere of influence of the hypermarkets. The smaller shops in the inner city were faced with a significant decrease in their sphere of influence. This phenomenon is the consequence of the decline of the local shop network, the segmented customer demands and the attractiveness of the large hypermarkets.

Employment dropped significantly after the political transition in 1989, however the decrease in the number of commuters was less spectacular. The importance of commuting gained in importance and became more essential for the smaller settlements located close to Eger.

The catchment area of the Eger hospital is determined by administrative policies, and it did not change significantly during the last 30 years.

The role of Eger in secondary education became clearly stronger, and the expansion of the hinterland of the respective institutes reflected massive growth. The catchment area of Eger covered settlements of neighbouring counties as well. This process was accelerated by the increase of the age of compulsory education, but demographic tendencies suggest a decrease in the degree of attraction in the future.

The complex hinterland of Eger has shown signs of shrinking since 1980, the set of strongly attracted settlements decreased. However, a significant increase was observed in the case of settlements that were target areas of suburbanisation during the last two decades. This Janus-faced process matches European tendencies which have also exhibited increasingly complex characteristics of urban-rural relationships in recent years.

\section{Bevezetés}

A társadalom térbeli szerveződésének kialakulásában alapvető szerepet játszanak a funkcionális alapon kiformálódó központ-vonzáskörzet-kapcsolatok (Benedek 2000), amelyek feltárása meghatározó a társadalom-földrajzi és a regionális tudományi vizsgálatok sorában.

Vonzáskörzetek központi funkciókkal rendelkező települések körül formálódnak, ahol a város és falu között létrejövő kapcsolatok, valamint a lakosság térbeli mozgásai településhálózatot hoznak létre (Hajdú, T. Mérey 1985). A vonzáskörzetet a központi település - sok esetben város - látja el központi funkciókkal és szolgáltatásokkal, amelyek nagyobb jelentőséggel bírnak, mint önmagában a centrumtelepülés lakosságszáma (Beluszky 1970). A vonzáskörzet függ a város által biztosított szolgáltatásoktól, ugyanakkor a vonzáskörzet meghatározza a központ méretét és funkcionális specializálódását (Murphey 1982). Arról megoszlanak a vélemények, hogy milyen funkciókat lehet központinak tekinteni, és ezek köre idővel változhat is. Néhány kutató (pl. Mendöl 1963, Beluszky 1967) a termelési kapcsolatokat - így a munkaerő ingázását - nem tekinti 
vonzáskörzet-alakító tényezőnek, ennek ellenére a legtöbb tanulmányban a munkaerő vonzódását is számításba veszik (pl. Beluszky 1981, Vadász 1981, Timár 1983, Pozder 1985, Bujdosó 2009a). ${ }^{1}$ A vonzáskörzet széles körü értelmezését támasztja alá, hogy azt az ellátó- és népességpótló területet is jelentheti, ahonnan a központi település népességcsere-mérlege aktív (Mendöl 1963, Dövényi 1977). Napjainkban azonban a szuburbanizáció jelensége ennek a folyamatnak az ellentettjét mutatja, azaz a vonzásövbe jelentős számú népesség költözik ki a centrumtelepülésről (Bajmócy 2003). Mindegyik nézőpontot egyesíti a leginkább egyszerüsítő definíció, amely a centrumtelepüléssel tényszerüen bizonyítható kapcsolatban lévő területet sorolja annak vonzáskörzetéhez (Dövényi 1977). Ennek ellenére - bár egyes szerzők munkáiban gyakran lehet hasonló nézeteket felfedezni - nem létezik egységes fogalmi meghatározás a vonzáskörzet definíciójára.

A fogalmi hiátusra magyarázatul szolgálhat, hogy ahány központi funkció létezik, gyakorlatilag annyi különböző vonzáskörzet vázolható fel. A vonzáskörzetek határának kijelölése nem egyértelmü, hiszen az egyetlen központhoz tartozó vonzásintenzitás-értékeken túl sokszor szükséges a környező centrumok vonzásértékeinek ismerete is (Bujdosó 2009a). Erre azért van szükség, mert a vonzáskörzetek gyakran átfedésben vannak egymással, és a funkciók kisugárzásának intenzitása különböző mértékben csökken a központtól való távolság növekedésével (Taylor 2004). A nemzetközi léptékü összehasonlítást pedig megakadályozza a vonzáskörzetek kialakulásának, történeti fejlődésének kontinensenként igen eltérő karaktere (Timár, Kovács 2009).

Ahogyan a településhierarchia és a funkciók is dinamikus jellegüek, a vonzáskörzeteket sem lehet statikus rendszerként értelmezni (Fodor, Hajdú 1985), tehát ugyanazon település adott központi funkcióihoz tartozó vonzáskörzet is átformálódhat idővel. Ritkán a szakirodalomban is lehet találkozni olyan tanulmányokkal, amelyek történeti vonzáskörzeteket próbálnak rekonstruálni (pl. Győri 2000), vagy a vonzáskörzetek időbeli változásának vizsgálatára vállalkoznak [pl. Debrecen (Papp 1981), Tiszafüred (Vadász 1981), Szolnok (Nagy 1988), Gyöngyös (Bujdosó 2009b) esetében történt erre kísérlet]. Az ilyen jellegű vizsgálatok csekély számának oka elsősorban az, hogy a korábbi hivatalos statisztikák nem kielégítőek egy dinamikai elemzés elvégzéséhez, a sokszor elengedhetetlen intézményi forgalmi és üzleti-piaci vevőszámlálási adatokat pedig igen nehéz - sokszor lehetetlen - összegyüjteni és rekonstruálni (Dövényi 1977). A komparatív jellegű vonzáskörzet-vizsgálatok további nehézségét jelenti, hogy a társadalmi-gazdasági változással átértékelődhetnek egyes indikátorok, sőt egész ágazatok jellemzői, így az összehasonlítás egyáltalán nem, vagy csak feltételekkel végezhető el. ${ }^{2}$ Jóval könnyebb az időbeli összehasonlító kutatást elkészíteni abban az esetben, ha az adott területre, városra korábban már készült vonzáskörzeti felmérés. Ennek hátránya azonban, hogy jelentősen beszűkülhet a kutatói mozgástér, mivel ragaszkodni kell az eredetileg alkalmazott módszertanhoz.

A vonzáskörzet-vizsgálatok hagyományos kutatási területet jelentettek a 
hazai és nemzetközi társadalomföldrajz és a kiformálódó regionális tudomány számára már az 1950-es évektől kezdve (Taylor 2004), azonban az elmúlt években megfigyelhető növekvő érdeklődéstől eltekintve a rendszerváltás után eléggé háttérbe szorultak hazánkban. Napjainkban Európában a vonzáskörzetvizsgálatok központi kérdését a vidék-város-kapcsolatok adják. E tanulmányok fö konklúziója az, hogy a kapcsolatok komplexebbé és kölcsönösen függővé váltak (Hoggart 2005). Hazánkban a politikai fordulat után lezajlott társadalmigazdasági változások; a területi-statisztikai illetve közigazgatási átszervezések által felértékelt körzet-kialakítás kérdése (pl. Kovács 2002) (részben legalábbis) igényt, a dinamikusan bővülő területi adatbázisok és a térinformatika pedig lehetőséget teremtenek kiterjedtebb elemzések elkészítésére.

Jelen tanulmányban kísérletet teszünk arra, hogy feltárjuk Eger aktuálisnak tekinthető, különböző ágazatokra vonatkozó, illetve komplex vonzáskörzetét, és hogy összehasonlító vizsgálat keretében vázoljuk fel annak rendszerváltás utáni átformálódását. Igyekszünk összegezni az elmúlt közel harminc évben a vonzáskörzetben bekövetkezett szerkezeti és területi változásokat, valamint további fontos célunk a háttérben meghúzódó ok-okozati viszonyok bemutatása is. Az empirikus vonzáskörzet-számításhoz szükséges összehasonlító értékeket Pozder Péter Egerre vonatkozó, 1984-ben és 1985-ben publikált eredményei szolgáltatták. Több esetben szükségszerűen kénytelenek voltunk eltérni az eredeti módszertantól, hiszen sokszor nem lehetett hozzájutni ugyanazon statisztikai adatokhoz. A tanulmány kereteit szétfeszítené a hivatkozott doktori dolgozat teljes reprodukálása, ezért mindössze néhány kiválasztott szegmens - a kereskedelmi, egészségügyi, oktatási, foglalkoztatási vonzáskörzet - elemzésére vállalkozunk. Tanulmányunk célja emellett az is, hogy a két vizsgálat közötti módszertani eltéréseket bemutassuk a vonatkozó részek esetében.

\section{A vonzáskörzet-számítás módszerei}

Ahogyan a bevezetés is rámutatott, a vonzáskörzetek feltárása korántsem egyszerü feladat, ehhez számos módszertani eszköz áll rendelkezésre (Beluszky 1981, Bujdosó 2009a).

A deduktív vizsgálati módszerek alapvető célja az, hogy statisztikai indikátorokon alapuló számítás segítségével lehessen kifejezni a központosultság mértékét a települések esetében - ezáltal pedig központokat tudjunk lehatárolni. Például a kereskedelmi forgalom értékeire elvégzett elméleti forgalomkülönbség kiszámítása nyújtott lehetőséget Heves megye kereskedelmi központjainak kijelölésére (Kovács 1987). Elméleti vonzáskörzetek lehatárolását a térinformatika segítségével is el lehet végezni - például az úgynevezett Voronoi-poligonok felhasználásával (Pearce 2000). 
A leggyakrabban alkalmazott deduktív vizsgálatok közé tartoznak a gravitációs modellek, amelyek a fizikai analógiájú metódusok csoportjába sorolhatóak. A gravitációs módszer - bár korlátok között, de - alkalmas lehet különféle térbeli áramlások intenzitásának becslésére, illetve az elméleti vonzáskörzetek lehatárolására (Dusek 2005). A számításhoz szükséges távolságadatok esetében egyre gyakrabban az időbeli elérhetőséget alkalmazzák (Tóth 2005). Számos hazai vizsgálat készült a gravitációs módszer segítségével, amelynek átalakított formáját (2SFCA) a nemzetközi szakirodalomban is gyakran használják, elsősorban egészségügyi ellátási területek optimalizálásának vizsgálata érdekében (McGrail, Humphreys 2009).

Az empirikus vizsgálati metódusok közül az úgynevezett ankétmódszerrel a központot felkereső lakosság megkérdezésével lehet feltárni a vonzáskörzetek jellemzőit. Ennek kétirányú megközelítési lehetőségét adja egyrészt a vonzáscentrumban megjelenő (környező) lakosság felmérése, másrészt a vonzáskörzetben élők kapcsolatteremtési, fogyasztói, igénybevevői szokásainak vizsgálata (Taylor 2004).

Az ügyfélszámlálás módszere az ágazati vonzáskörzetek - közlekedési kapcsolatok, kereskedelem, munkaerő vonzása, oktatás, egészségügy, egyéb központi funkciók - vizsgálatának alapvető elemzési lehetősége.

Az interurbán telefonhivások kiértékelése a települések közötti kapcsolatok feltérképezésének klasszikus módszerét jelenti (Tóth 1977, Pozder 1984), mára azonban - részben a mobiltelefonok elterjedése miatt - jelentősen csökkent a szerepe (Bujdosó 2009a). Sőt, a telekommunikáció dinamikus fejlődése az üzleti kapcsolatok alapján kirajzolódó városi vonzáskörzetek teljes átfedéséhez vezet (Taylor 2004).

A különböző funkciók összehasonlíthatóságának nehézségei ellenére szinte minden kutató kísérletet tett arra, hogy összegzett, komplex vonzáskörzeti képet tárjon fel, amely visszatükrözi egy központi településnek és környékének kapcsolatrendszerét.

A szakirodalomban leggyakrabban használt módszer első alkalmazása Beluszky Pál nevéhez füződik (Beluszky 1970), amelynek lényege, hogy először minden egyes funkción belül az átlagos vonzásintenzitási értékeket kell meghatározni. Ezután az értékek lakosságszámra vetített homogenizálása és mátrixtáblába rendezése következik. Az egyes településekre jellemző értékek, valamint az átlagtól való eltérés hányadosainak megállapítása után a kapott hányadosok négyzetösszegéből négyzetgyök vonásával kaphatóak meg a vonzódást kifejező mutatószámok. A komplex vonzáskörzet kiszámítható a központtal való kapcsolatteremtések száma alapján is (súlyozás beiktatásával) (Pozder 1984). 


\section{Eger fejlődése és térségi szerepe}

Eger Heves megye székhelyeként Észak-Magyarország meghatározó vonzásközpontja. A város és a körülötte létrejött településcsoport nagyobbik része a Bükk nyugati és déli lábánál fekvő Szóláti-, Laskó-, Eger-, Tárkányi-, Ostoros-, és Novaji patakok völgye között változatos felépítésủ dombvidéken terül el. A természeti viszonyok nemcsak Eger kialakulását és terjeszkedési lehetőségeit határozták meg, de a vonzáskörzet elhelyezkedését és nagyságát is befolyásolták (Pozder 1984, Kovács 1987).

Központi szerepét Eger elsősorban nem a közlekedési kapcsolatainak köszönheti, hiszen nem tekinthető kiemelt közlekedési csomópontnak, mivel elkerülik mind a közúti, mind a vasúti fövonalak (Pozder 1985).

Eger története hosszú múltra tekint vissza, mivel a Szent István által alapított 5 püspökség egyikének székhelye lett, és ezáltal vált a kialakuló feudális magyar állam egyik egyházi-politikai központjává (Pozder 1984). Eger várossá fejlődését meghatározta helyzeti energiája, mivel az alföldi és a hegyvidéki jellegü tájak határán a megtermelt javak kicserélésének színteréül szolgált, és így vált a környék legnagyobb kereskedelmi központjává (Gyimesi 1975). Stratégiai pozícióját erősítette a vár megépítése is. A török kiűzése után az igazi fellendülés és a virágzás időszakának a 18. század bizonyult, amelyben fontos szerep jutott a bortermelésnek (Kleb 1978). Ugyanakkor a 19. század második felétől jellemző általános magyarországi városfejlődés elmaradt, ugyanis a vasútépítések és az ipartelepítési hullám kevésbé érintették. A 19-20. század fordulóján Egert csak kulturális élete emelte a többi kisváros fölé (Pozder 1984). A második világháború után megindult a megyeközpontok tervszerű fejlesztése, ezáltal Egerben is jelentős gazdasági fejlődés volt tapasztalható. Érdemes azonban megemlíteni, hogy Eger fejlődése ebben az időszakban sem volt olyan dinamikus, mint a környező jelentős központoké. Ennek hatására Eger komplex jelzőszámmal mért elméleti vonzáskörzete (úgynevezett szupergravitációs index) zsugorodott Miskolc és Szolnok előnyére (Papp 1981). A város hatósugarának fejlődését kelet felől behatárolta Borsod-Abaúj-Zemplén megye közelsége, amely főleg az adminisztratív jellegű funkciók kiteljesedését gátolhatta (Bujdosó 2009a).

Az 1960-as évektől a város szívóhatásának köszönhetően jelentősen gyarapodott a népességszám, főleg a környező falvakból beáramló tömegek miatt. 1960 és 1980 között 38671 főről 60897 főre nőtt a lakosságszám. Az 1980-as évektől kezdve ellentétes irányú folyamat rajzolódott ki, mivel egyre hangsúlyosabbá vált az Egerből a környező falvak irányába történő kiköltözés. Az 1990es évtizedben ez a tendencia felerősödött, aminek eredményeként Eger környékén is megindultak a szuburbanizációs folyamatok. A város lakosságszáma 2010-re 56530 före mérséklődött (Bodor 2009). 
Megyeszékhelyként Eger számos olyan központi funkcióval rendelkezik, amelyek túlmutatnak a középfokú szerepkörön. Lakosságszámához képest a város előkelő helyen áll a megyei és regionális szintű dekoncentrált államigazgatási szervek központjainak számát tekintve. Az elmúlt időszakban Eger jelentősen profitált a szervezetek központjainak áthelyezéséből, 8-9. helyen állt a városok rangsorában (Kozma 2008).

Jelen vizsgálatban elsősorban a középfokú funkciókra helyezzük a hangsúlyt, és néhány kiemelt ágazat vonzáskörzeti jellemzőit, az elmúlt közel három évtizedben bekövetkezett változási tendenciáit külön is ismertetjük.

\section{Eger kereskedelmi vonzáskörzete}

A kereskedelem nagyon fontos szerepet játszik a településhálózat életében, hiszen összekötő kapocsként szolgál a termelői és a fogyasztói szféra között. Befolyásolta a településhálózat hierarchikus és differenciált létrejöttét, emiatt kötődik a központi funkciók jelentős részéhez (Erdősi, Hajdú, Hrubi 1985). A vonzáskörzet-vizsgálatokban kiemelten fontos ágazat, hiszen a kereskedelem hozza létre a város és a falu között a legszorosabb kapcsolatot és legteljesebb értékü vonzáskörzeti rendszert. Ezenkívül kiemelendő, hogy az adminisztratív kötöttségek alig befolyásolják területi kiformálódását, ugyanakkor a központok kialakulásában döntő tényezőként szerepel a földrajzi fekvés (Beluszky 1966). A kiskereskedelmi vonzás által kialakított kapcsolatok tartósak, csak lassan változnak (Kovács 1986), sőt a kereskedelem a térkapcsolatok szempontjából konzervatív funkciónak tekinthető (Kovács 1987). Fontos azonban hangsúlyozni, hogy a piacgazdaságra való áttérés óta lezajlott változások (a kiskereskedelmi egységek tömeges elterjedése és differenciálódása, a javuló áruellátás, a szuperés hipermarketek megjelenése, új fogyasztási formák megjelenése) (Bujdosó, Remenyik 2009) érzékelhető módon hatottak a kereskedelmi vonzáskörzetekre is. Emiatt tanulmányunkban nagyobb figyelmet szentelünk Eger kereskedelmi vonzáskörzete összehasonlító elemzésének.

Eger a legfontosabb kereskedelmi központ Heves megyében, bár az 1980-as években az egy lakosra jutó kereskedelmi forgalom alapján Gyöngyös megelőzte (Kovács 1986). Gyöngyös jelenlegi kereskedelmi szerepére utal, hogy esetében a 10000 lakosra jutó kiskereskedelmi üzletek száma 2009-ben meghaladta az egri értéket. Abszolút méreteit tekintve azonban Eger vezető szerepe vitathatatlan a megyében.

Pozder Péter 1980-ban kiskereskedelmi üzletek vásárlóit és az egri piac termelőit mérte fel. Jelen vizsgálatban - a piacgazdasági átalakulás következtében - nem tudtuk ugyanazokat a kereskedelmi egységeket felmérni, ezért négy különböző kiskereskedelmi ágazat belvárosban található szaküzletét - élelmiszer, ruházat, elektronika és számítástechnika, lakberendezés - választottuk ki, ahol a 
vásárlókat egy héten keresztül, munkanapokon, az üzletek nyitva tartási idejében kérdeztük lakóhelyükről. Véleményünk szerint a nagyméretű szakáruházak és hipermarketek kereskedelmi vonzáskörzete túlmutathat a középfokú szinten, azonban ezek figyelembevétele nélkül nehezen lehetne detektálni a kiskereskedelem átalakulásából fakadó hatásokat és Eger valós kisugárzó hatását. Emiatt két, szuper-és hipermarketeket üzemeltetö üzletlánc egri egységeire vonatkozó vevőszámlálási adatokat is összegyüjtöttünk. ${ }^{3}$

Pozder Péter az 1980-ban felmért 19376 fős vásárlói minta alapján azt állapította meg, hogy a vevők 54\%-a volt egri. A 2009-2010-ben, egy héten lezajlott vevőszámlálások során a belvárosban 9645 vásárlót sikerült megkérdezni, a nagyáruházak esetében pedig 40744 vevőt regisztráltak. A belvárosi üzletek vevőinek 66\%-a volt helyi lakos, a nagyáruházakénak pedig 62\%-a. Az általunk készített összesítés során a vevők 62,8\%-a volt egri, azaz a máshonnan bejáró vásárlók aránya 46\%-ról mintegy 37\%-ra esett vissza. Ezek az adatok jelzik, hogy az eltelt időszakban egyértelmüen csökkent a vidéki vásárlók aránya.

Eger kiskereskedelmi vonzáskörzetének határát Pozder a 4 vásárló/100 lakos értéknél húzta meg. Ennek megfelelően szerkesztettük meg az Eger kiskereskedelmi vonzásterületére vonatkozó térképet, amely szemlélteti a vizsgált időintervallumban bekövetkezett változásokat (1.ábra).

1. ábra: Eger kiskereskedelmi vonzáskörzete a 100 lakosra jutó heti vásárlások száma , 2010-201 1

The commercial hinterland of Eger by the number of purchasings per 100 inhabitants, 2010-2011

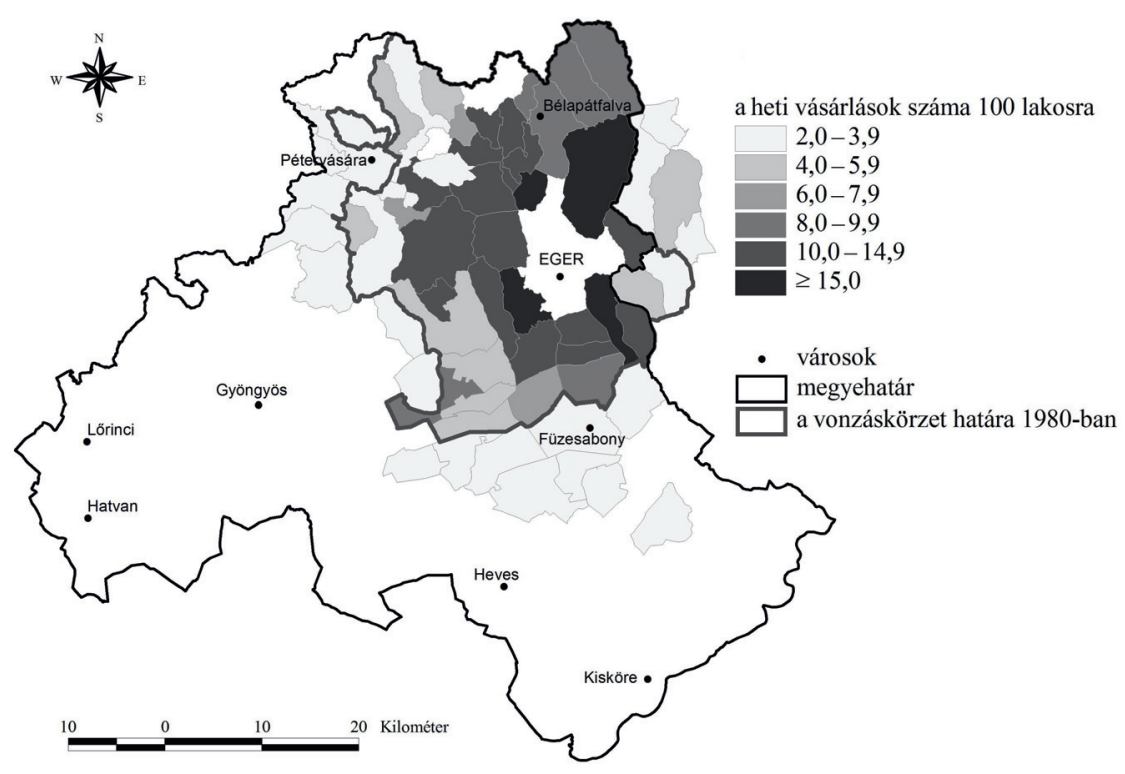

Forrás: a vevőszámlálás adatai alapján a szerzők saját szerkesztése. 
Az 1980-as vizsgálattal való összehasonlíthatóság érdekében korrigáltuk a minta értékeit. ${ }^{4}$ Ez a korrekció azért volt szükséges, hogy összevethető legyen a két felmérés területi mintázata. Jogosan felmerülhet azonban, hogy így a vásárlók valós számát nem lehet összehasonlítani. Erre egyrészt akkor nyílt volna lehetőségünk, ha rendelkezésre álltak volna a pontos települési adatok 1980-ból (ezekhez nem tudtunk hozzájutni), illetve akkor, ha mindkét vizsgálat az összes Egerben vásárlót számba tudta volna venni egy adott héten. Nyilvánvalóan erre nem volt lehetőségünk, mivel az 1980-ban Egerben található 207 kiskereskedelmi bolt száma 2009-re 1371-re bővült. Ennek oka egyrészt a rendszerváltás utáni piacgazdasági átalakulás, másrészt a vásárlói igények szegmentálódása és sokszínűbbé válása.

Az összehasonlításból egyértelműen kitűnik, hogy a vásárlások gyakorisága növekedett, 2009-2010-ben már 19 település esetében volt 10,0 fölötti a 100 lakosra jutó vásárlások száma, míg 1980-ban csak 13 község esett ebbe a csoportba. A még erősebben, 15,0 fölötti értékkel vonzódó települések száma négyre (Egerszalók, Felsőtárkány, Ostoros, Szarvaskő) bővült a korábbi kettőről. Ugyanakkor az 1980-ban még kompakt vonzásöv mozaikosabbá vált, és egyértelmüen csökkent a kiterjedése.

A kétfajta kiskereskedelmi egység típusainak vonzáskörzetei között érdemi különbség látható (terjedelmi korlátok miatt csak a legfontosabb észrevételeket tettük meg). A hipermarketek vonzásövezete kompaktabb és koncentrikusabb (fontosabb a földrajzi közelség), mint a belvárosi üzletek hinterlandja. Ugyanakkor Bélapátfalva és a tőle északkeletre fekvő községek (Szilvásvárad és Nagyvisnyó) karakteresen megjelentek a hipermarketek vonzáskörzetében, míg a belvárosi üzletekében alig. Ennek hátterében az áll, hogy Bélapátfalva kiskereskedelmi üzleteinek 100 lakosra vetített száma 1980-hoz képest 0,6-ről 1,2-re nőtt, amivel a város és a környező községek alapvető cikkekkel való ellátása biztosítottá vált (Bujdosó, Remenyik 2009). Azonban a hipermarketek árukínálata és árszintje képes vonzást gyakorolni ezekre a településekre is. Hasonló jelenség figyelhető meg az Egertől délre eső községek esetében is.

\section{Eger foglalkoztatási vonzáskörzete}

Ahogyan a bevezetésben már taglaltuk, a kutatói vélemények megoszlanak a munkaerővonzást illetően. A rendszeres munkahelyi ingázás utazási költségei általánosságban véve is drágának mondhatók, ezek leginkább az alacsony bérszinttel rendelkező rétegeket sújtják, és az ingázás jelentőségének csökkenéséhez vezetnek (Kertesi 2000). A rendszerváltás után a foglalkoztatás visszaesése a megyeszékhelyekre ingázók számának csökkenését is eredményezte (Pénzes 2010).

Az Egerbe napi ingázást végzőket a lakóhelyükön élő aktív keresők százalékában vizsgáltuk, a KSH 2001-es népszámlálási adatai alapján (a 2011-es nép- 
számlálás eredményei még nem érhetők el). A munkaerővonzás határát - Pozder Péter munkájához igazodva - a 20\%-os értéknél vontuk meg. Ennek megfelelően 29 település tartozott Eger vonzáskörzetébe, ahonnan összesen 7103 fö járt be naponta Egerbe dolgozni (Szarvaskő ekkor még közigazgatásilag Eger része volt, azonban okkal feltételezhető, hogy szintén Eger vonzáskörzetét alkotta) (2. ábra). 1980-ban 22 település tartozott ebbe a kategóriába, ahonnan 7800 fó ingázott a megyeszékhelyre. Következtetésként elmondható, hogy bővült a vonzott települések köre, de jelentősen csökkent az egy településre jutó bejáró dolgozók abszolút száma. Ellentmondás, hogy az ingázóknak a helyben lakó foglalkoztatottakhoz viszonyított aránya mégis növekedett. Ennek oka, hogy az említett településeken nagyobb mértékben csökkent a foglalkoztatottak tényleges száma. Összegezve megállapítható, hogy jelentősebb volt az aktív keresők számának csökkenése, mint a megyeszékhelyre napi ingázást folytatóké.

Eger foglalkoztatási vonzáskörzete jelentős változásokon ment keresztül 30 év alatt. Az akkori vonzáskörzetbe tartozó települések közül csak Cserépváralja, Mezőszemere és Kömlő esett ki, viszont Szomolya és Bogács mellett még két Borsod-Abaúj-Zemplén megyei település, Bükkzsérc és Cserépfalu is 20\% feletti érték-

2. ábra: Eger foglalkoztatási vonzáskörzete az Egerbe ingázóknak

a foglalkoztatottakhoz viszonyított aránya alapján, 2001

The commuters' belt of Eger by the employees commuting to Eger in the ratio of the employees, 2001

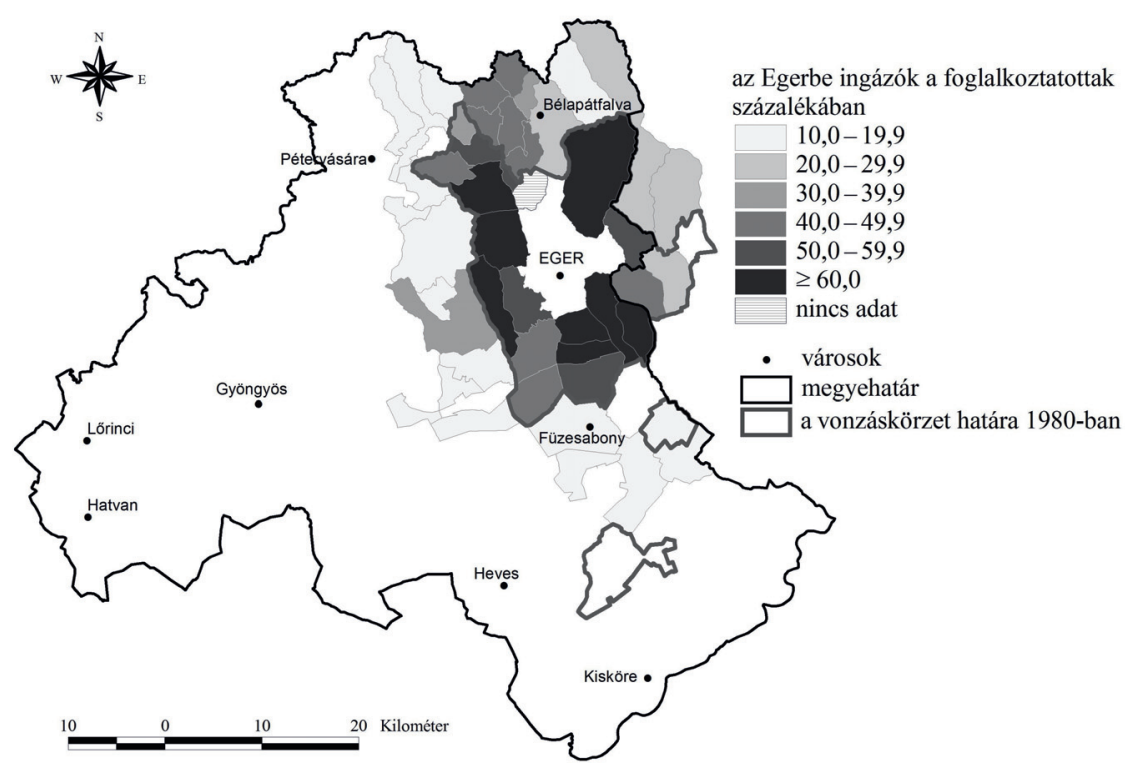

Forrás: a KSH 2001-es népszámlálási adatai alapján a szerzők saját szerkesztése. 
kel rendelkezett 2001-ben, tehát keleti irányban szélesedett a vonzáshatár. Nagyon fontos és rendkívül feltűnő változás állt be az Egertől északra található térségben. A Bélapátfalvai kistérség települései - Szilvásvárad kivételével - 2001-re már Eger vonzásövébe kerültek. Ennek oka, hogy a cementgyár fokozatos leépülésével és 2002-es végleges bezárásával Bélapátfalva elveszítette korábban jelentősnek mondható foglalkoztatói szerepkörét. A Füzesabonyi kistérség irányában éles a határvonal, hiszen egyetlen település sem tartozott a vonzásövbe. Az Egri kistérségből mindössze Feldebrő és Tarnaszentmária ingázóinak aránya nem érte el a küszöbértéket.

\section{Eger oktatási vonzáskörzete}

Eger Heves megye legfontosabb oktatási központja mind a felsőoktatást, mind a középfokú oktatást tekintve. Oktatási szerepköre a megyeszékhelyek rangsorában is kiemelkedö (Fodor, Hajdú 1985). Tanulmányunkban nem foglalkozunk az Eszterházy Károly Főiskola vonzáskörzetével, hiszen az meghaladja a középszintet, kiterjed az egész ország területére. A vizsgálat alapját tehát az egri középiskolák adták. Pozder felmérése az 1979/1980-as tanévben regisztrált 9 középfokú oktatási intézmény adatain alapult, amelyekből 3 volt gimnázium. 2010-ben már 14 középfokú oktatási intézmény müködött Egerben, és 8 középiskolában folyt gimnáziumi szintủ oktatás.

A középfokú iskolák vonzáskörzetét a tanulók lakóhely szerinti számának 100 lakosra vetítésével határoztuk meg. A 2010/2011-es tanévben Eger középfokú iskoláiba járó tanulóinak lakóhelyét az oktatási intézmények szolgáltatták számunkra. Az adatgyüjtés akadályokba ütközött, ugyanis három intézmény többszöri megkeresésre sem adott számunkra információkat, így összesen 11 intézmény adatai ${ }^{5}$ alapján készült el a vonzásintenzitási térkép (3. ábra).

Az 1979/1980-as tanévben az Egerben tanulók száma 6169 fö volt, amelynek 70,6\%-át alkották vidékiek, azonban a 2010/2011-es tanévben már 7057 fó járt az egri intézményekbe (az említett három intézmény tanulóit leszámítva), és 76,3\%-uk volt vidéki, tehát a más településekről érkezők száma és aránya is nőtt. Pozder vizsgálatában az 1 tanuló/100 lakos értékkel határolta le a középfokú oktatási vonzáskörzetet. Ehhez alkalmazkodva végeztük el a számításokat, amelyek alapján több jelentősnek mondható változás is megállapítható. A figyelembe vett két időpont között Eger oktatási vonzáskörzete vált a legkiterjedtebbé.

A vonzáskörzet déli határa valamelyest szűkült 2010-re, azonban nyugati irányba bővült a vonzásterület. A megyeszékhelytől keletre fekvő Borsod-AbaújZemplén megyei települések megerősödött vonzódása is kimutatható. 1979/1980ban 8 borsodi község tartozott Eger oktatási vonzáskörzetébe, a 2010/2011-es tanévben már 21. Összesen 100 település alkotta Eger középfokú oktatási vonzáskörzetét, ami 17-tel több, mint a 30 évvel korábbi vizsgálatban. 
3. ábra: Eger középfokú oktatási vonzáskörzete az Egerben tanuló középiskolások

100 lakosra vetített száma alapján a 2010-2011-es tanévben

The secondary school hinterland of Eger by the number of students per 100 inhabitants in the schoolyear 2010-2011

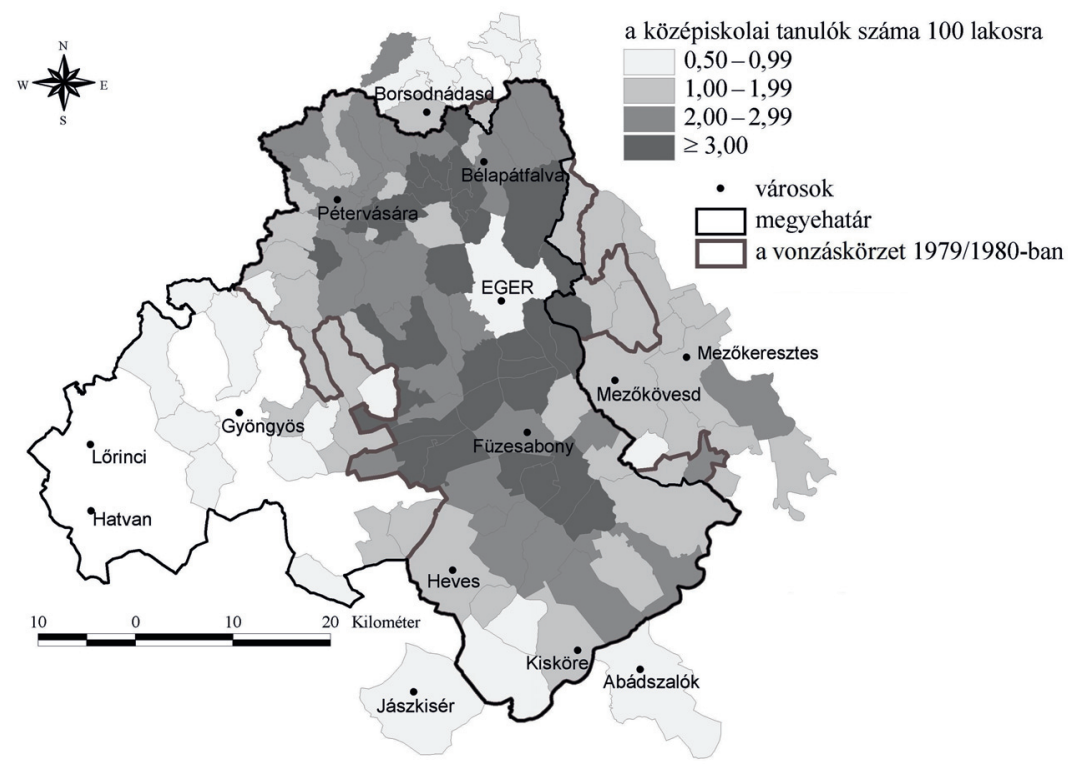

Forrás: a középiskolák adatszolgáltatása alapján.

Az oktatási vonzáskörzet határainak kiterjedését elsősorban a közlekedés határozza meg (Pozder 1985), valamint a középfokú oktatás más városokban való jelenléte. Az Egerrel közvetlenül érintkező települések mellett a közúton gyorsabban elérhető települések esetében jelentkeztek a legmagasabb értékek. A 33-as föút mentén fekvő községek - Dormánd, Besenyőtelek - esetében a mérőszám értéke 3 feletti (Füzesabony értéke alacsonyabb, mivel saját középiskolával rendelkezik). A megállapítás igaz a Gyöngyös felé vezető 3-as foút - Kerecsend, Kápolna, Kál - és az északról Egerbe futó 25-ös foút menti települések - Szarvaskő, Egercsehi, Szúcs - esetében is. Ez utóbbiak intenzitási értékeiben egyértelmüen megmutatkozik, hogy Bélapátfalva városi rangja ellenére sem rendelkezik középiskolával.

A teljesebb oktatási ingázási kép érdekében összehasonlítást végeztünk az iskolába ingázók számával a 2001-es népszámlálási adatok alapján. 2001-ben szűkebb területen, azonban jóval intenzívebben jelentkezett Eger vonzása. Ennek oka kereshető abban, hogy a népszámlálás felmérése teljes tanulói létszámot jelentett - az általános iskolába és főiskolára naponta ingázó tanulókat is figyelembe véve megközelítőleg 10000 föt. Ugyanakkor a középfokú vonzáskörzet 2010-11-re megfigyelhetó kiterjedése elsősorban a kötelező oktatás korhatárának emelé- 
sére vezethetö vissza, tehát alapvetően adminisztratív oka van (a teljes ingázó tanulói létszám növekedése még jelentősebb lehetett, de ennek felmérésére nem volt módunk). A jelenlegi demográfiai tendenciák miatt azonban a jövőben várhatóan gyengülni fog Eger oktatási vonzása. Ennek jelei már mutatkoznak az intenzitási értékekben is (pl. az elöregedő lakosságú Fedémes esetében).

\section{Eger egészségügyi vonzáskörzete}

Eger a legnagyobb egészségügyi ellátó Heves megyében. Az egészségügyi vonzáskörzet meghatározásához az egri Markoth Ferenc Kórház fekvőbetegforgalmi adatait használtuk fel. A kapott adatbázis a 2010. januártól augusztusig terjedő nyolc hónapot fedte le, amelyből két hónapot választottuk ki annak érdekében, hogy az 1980-as vizsgálattal összevethető legyen. A vizsgált két hónapban 6019 beteget vettek fel, 25,7\%-uk volt egri. Ez valamivel kevesebb, mint 1980-ban, amikor az 5453 felvett betegnek 28,7\%-a volt helyi lakos. $A z$ egészségügyi intézményekre jellemzo", hogy vonzáskörzetük adminisztratív úton megállapitott határokhoz kötött, meghatározott felvevő területtel rendelkeznek. Eltérés tapasztalható azonban az egyes osztályok vonzáskörzeti határai között. Azok az osztályok, amelyek csak Egerben működnek (reumatológia, urológia, érsebészet stb.) az egész megye lakosságát fogadják. Az úgynevezett általános osztályok (belgyógyászat, sebészet, fül-orr-gégegyógyászat, csecsemő- és gyermekgyógyászat stb.) az Egri, a Pétervásárai, a Füzesabonyi és a Hevesi kistérséget látják el Tarnazsadány, Boconád, Tarnaméra, Zaránk, Erk és Tarnaörs településeket kivéve. A felvevőterület határa ezen települések mentén húzható meg, a határvonal nem változott a 30 évvel ezelőtti vizsgálathoz képest. Lényeges különbség azonban, hogy ma már nem látja el egyik osztály sem ózd és az akkori ózdi járás településeit. Viszont néhány esetben ma is túlnyúlik a megyehatáron a felvevőterület. A reumatológiai osztály fogadja a Szomolyáról érkező betegeket, az ortopédia Szomolya mellett Bogács és Borsodivánka lakosságát is ellátja.

Ennek megfelelően leszürhető, hogy lényeges változás nem következett be az 1980-as állapothoz képest, valamint az intenzitási tendenciákat tekintve is hasonló kép rajzolódik ki. Mégis érdemes néhány meghatározó jellemvonást megemlíteni:

- Jól elkülöníthető erős vonzásintenzitással rendelkező településhalmaz jelenik meg Egertől északi, valamint északnyugati irányban egészen a megyehatárig. Ezen a területen erősödő vonzódás figyelhető meg.

- Az Egertől délre fekvő Füzesabonyi és az egyébként is megosztott Hevesi kistérség települései körében csak mozaikszerüen jelentek meg az erősebben vonzódó települések, és a vonzásintenzitás változása is kétirányú. 


\section{Eger komplex vonzáskörzete}

A figyelembe vett ágazatok alapján számított vonzásintenzitási értékeket a tanulmány második alfejezetében bemutatott módon - Beluszky Pál módszerét alkalmazva - összesítettük (4. ábra).

Az összesítéssel kapott eredmények legfontosabb jellemzője az, hogy a Pozder Péter által is figyelembe vett küszöbérték szerint legerősebben vonzódó települések összefüggő zónát alkotva szegélyezik Egert (Pozder 1984). Az erősen és közepesen vonzódó települések esetében azonban már mozaikosabb a kép, néhány Borsod-Abaúj-Zemplén megyei község (Borsodszentgyörgy, Bükkábrány, Mezőnagymihály, Négyes, Tiszavalk) csak szigetszerüen vonzódik Egerhez. Fedémes pedig Eger összefüggő vonzásterületén belül gyengén vonzódónak minősült. A közepes intenzitással vonzódó települések esetében többször csak egyetlen ágazat - például az oktatás - esetében jelentkezett erőteljesebben Eger vonzása. Ugyanakkor a borsodi települések vonzáskörzeti „hovatartozásának" reális meghatározásához ismerni kellene Miskolc vonzásának hatását is (különösen Bükkábrány esetében).

Bár az 1980-as vizsgálat pontos eredményei nem álltak rendelkezésre, néhány tendencia egyértelműen kiolvasható (1. táblázat).

4. ábra: Eger komplex vonzáskörzete az átlagtól való eltérés alapján The complex hinterland of Eger by the deviation from average

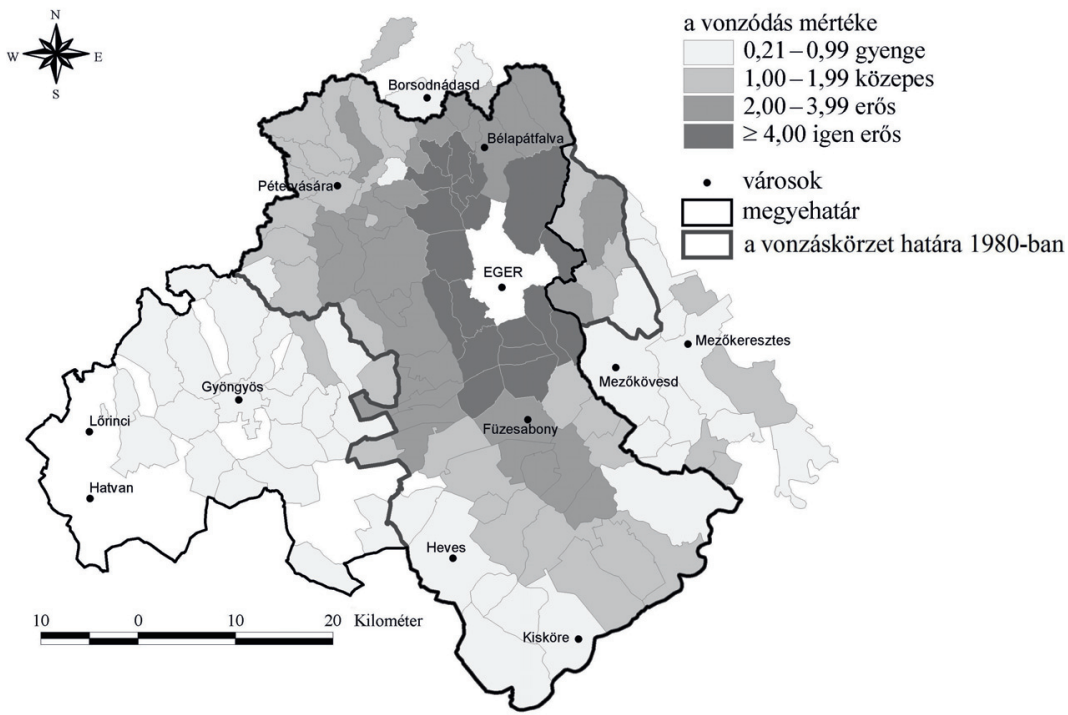

Forrás: az összegyưjtöłt adatok alapján saját számítás. 
1. táblázat: A vonzott települések száma és lakosságszáma, 1980, 2010 The number and population number of the settlements attracted by Eger, 1980, 2010

\begin{tabular}{lcccc}
\hline \multirow{2}{*}{ A vonzás } & \multicolumn{2}{c}{ 1980-ban } & \multicolumn{2}{c}{ 2010-ben } \\
\cline { 2 - 5 } & $\begin{array}{c}\text { a települések } \\
\text { száma }\end{array}$ & $\begin{array}{c}\text { a lakosságszám, } \\
\text { fö }\end{array}$ & $\begin{array}{c}\text { a települések } \\
\text { száma }\end{array}$ & $\begin{array}{c}\text { a lakosságszám, } \\
\text { fö }\end{array}$ \\
\hline igen erôs & 25 & 59400 & 18 & 27429 \\
erös & 44 & 88434 & 28 & 45912 \\
közepes & 15 & 26478 & 36 & 45311 \\
\hline Összesen & 84 & 174312 & 82 & 118652 \\
\hline
\end{tabular}

Forrás: Pozder Péter vizsgálata és a saját számítás alapján.

Az intenzivebben vonzott települések köre és az összesitett lakosságszámuk egyértelmüen csökkent. A közepesen erősen vonzott települések köre ennek megfelelően bővült. Különösen Heves megye déli részén szembetünő a komplex vonzás csökkenése. Azonban az is kiderült, hogy a vonzás mértéke jellemzően növekedett Felsőtárkány, Ostoros, Andornaktálya és Novaj esetében 1980-hoz képest (a maximumérték 2010-re 7,35-ról 9,23-ra nőtt). Tehát, míg Eger összesített vonzáskörzete jellemző módon csökkent, a közelében fekvő - és a szuburbanizáció által leginkább érintett - községek esetében erősödött a vonzás intenzitása.

\section{Összegzés}

Konklúzióként elmondható, hogy a különböző ágazati vonzáskörzetek esetében eltérő folyamatok figyelhetők meg. A kiskereskedelmi kapcsolatok összvolumene nőtt, azonban a vidéki vásárlók aránya csökkenést mutatott. A hipermarketek nagyobb vonzásövvel rendelkeztek, mint a kisebb belvárosi üzletek, összességében mégis jellemzően csökkent Eger kereskedelmi vonzáskörzete 1980-hoz képest.

Az ingázóknak a foglalkoztatottak számához mért aránya alapján számított foglalkoztatási vonzáskörzet kiterjedt ugyan, de ez összességében kevesebb Egerbe ingázót jelentett 2001-ben, mint 1980-ban, tehát Eger foglalkoztatási szerepe relatíve felértékelődött.

Az egészségügyi vonzáskörzet adminisztratív úton meghatározott, és nem következett be jelentős változás a vizsgált időintervallumban.

Az oktatási vonzáskörzet egyértelműen kiterjedt, és az Egerbe ingázó középiskolai diákok száma is nőtt, elsősorban a tankötelezettség korhatárának emelése miatt. Ugyanakkor ennek az ágazatnak a szerepe a jövőben vissza fog szorulni a gyermekszám csökkenésének következtében.

A komplex vonzáskörzet-számítás alapján elmondható, hogy Eger hinterlandja összességében véve zsugorodott 1980-óta. Az erősebben vonzott települések száma csökkent, és a legjellemzőbb visszaszorulás Heves megye délkeleti részében fi- 
gyelhető meg. Ezzel párhuzamosan ugyanakkor egyértelmüen látszik az Eger közelében fekvő szuburbanizációs céltelepülések intenzívebbé vált kapcsolata is.

Ez a megfigyelés alátámasztja az európai tendenciákat, azonban a különböző ágazatok eltérő sajátosságai mindenképpen figyelmet érdemelnek. További kutatások szükségesek annak kiderítésére, hogy az Eger esetében feltárt tendenciák más nagyvárosok esetében is jellemzőek-e.

\section{Köszönetnyilvánítás}

A tanulmány a TÁMOP-4.2.2/B-10/1-2010-0024 pályázat támogatásával készült.

\section{Jegyzetek}

1 A szakirodalomban ugyanakkor lehet találkozni pusztán a munkaerő ingázását alapul vevő vonzáskörzet-vizsgálatokkal is (pl. Faluvégi 2008, Pénzes 2010), sőt olyan tanulmány is készült, amely a vonzásviszonyokat a foglalkoztatási ingázás alapján értékeli több időmetszetben is (Nagy 1988). Fontos ugyanakkor leszögezni, hogy csak kellő indokkal lehet mindössze egyfajta térkapcsolat alapján vonzáskörzeteket lehatárolni.

2 Indikátorok átértékelődésére példa az interurbán telefonhívások száma, amely évtizedekkel ezelőtt nagyszerűen alkalmas volt akár nagyobb területek kapcsolatrendszerének feltárására (Tóth 1977), mára a távközlési szektor liberalizálása és a mobilkommunikáció elterjedése miatt viszont veszített jelentőségéből. Hasonlóképpen, a kiskereskedelem szabályozásának változása és az új szereplők megjelenése teljesen átalakította az ágazati környezetet, egyben az összehasonlító vizsgálat körülményeit is.

3 Az üzletláncok nevét a kérésükre nem hozhatjuk nyilvánosságra, és adataikat is csak összevonva szerepeltettük.

4 A korrekció úgy történt, hogy a rendelkezésre álló vásárlói adatok megközelítőleg 50000 fős összértékét lecsökkentettük a Pozder-féle vizsgálat értékére úgy, hogy a települések közötti arányok nem változtak.

5 Az adatokat rendelkezésünkre bocsátó intézmények: Dobó István Gimnázium, Gárdonyi Géza Gimnázium, Bornemissza Gergely Szakközép-, Szakiskola és Kollégium, Eszterházy Károly Gyakorló Általános Iskola, Középiskola és Alapfokú Művészetoktatási Intézmény, Pásztorvölgyi Általános Iskola és Gimnázium, Egri Kereskedelmi Mezőgazdasági, Vendéglátóipari Szakközép-, Szakiskola és Kollégium, Szent Lőrinc Vendéglátó és Idegenforgalmi Szakközépiskola, Szakiskola és Kollégium, Kossuth Zsuzsa Gimnázium Szakközépiskola és Kollégium, Szilágyi Erzsébet Gimnázium és Kollégium, Neumann János Középiskola és Gimnázium, Wigner Jenő Műszaki, Informatikai Középiskola és Kollégium.

\section{Irodalom}

Bajmócy P. (2003): Az elővárosi fejlődés migrációs vonatkozásai az Alföldön. Alföldi Tanulmányok, 19., 84-98.

Beluszky P. (1966): Magyarország kiskereskedelmi központjai. Földrajzi Értesito”, 2., 237-261. 
Beluszky P. (1967): A magyarországi városok vonzáskörzetei. Kandidátusi értekezés tézisei, Debrecen

Beluszky P. (1970): A falu-város közötti kapcsolatok vizsgálati módszerei. Területi Statisztika, 4., 368-380.

Beluszky P. (1974): Nyíregyháza vonzáskörzete. A város-falu közötti kapcsolatok jellege és mennyiségi jellemzői Szabolcs-Szatmár megyében. Akadémia Kiadó, Budapest (Földrajzi Tanulmányok; 13.)

Beluszky P. (1981): A városi vonzáskörzetek (városkörnyékiség) vizsgálatának elvi-módszertani kérdései. Államigazgatási Szervezési Intézet, Budapest

Benedek J. (2000): A társadalom térbelisége és térszervezése. Risoprint, Kolozsvár

Bodor N. (2009): Az Egri agglomerálódó térség szuburbanizációs folyamatainak vizsgálata. Szakdolgozat, Debreceni Egyetem, Debrecen

Bujdosó Z. (2009a): A megyehatár hatása a városok vonzáskörzetére Hajdú-Bihar megye példáján. Debreceni Egyetemi Kiadó, Debrecen (Studia Geographica; 24.)

Bujdosó Z. (2009b): Gyöngyös város vonzáskörzetének változása az elmúlt negyedszázadban. Földrajzi Közlemények, 1., 59-74.

Bujdosó Z., Remenyik B. (2009): Kereskedelmi vonzáskörzet-kutatás elmélete és gyakorlata Heves megyei példákon keresztül. In: Pajtókné Tari I., Tóth A. (szerk.): Változó Föld, változó társadalom, változó ismeretszerzés. EKF, Eger, 175-180.

Dövényi Z. (1977): A vonzáskörzetek történeti kialakulásának s változásának vizsgálati lehetőségeiről. Alföldi Tanulmányok, 1., 132-142.

Dusek T. (2005): Térbeli egymásrahatások, szociálfizikai modellek. In: Nemes Nagy J. (szerk.): Regionális elemzési módszerek. ELTE Regionális Földrajzi Tanszék, MTA-ELTE Regionális Tudományi Kutatócsoport, Budapest, 237-245. (Regionális Tudományi Tanulmányok; 11.)

Erdősi F., Hajdú Z., Hrubi L. (1985): A vonzáskörzeti viszonyok átalakulása Baranya megyében a felszabadulás óta. In: Ádám A., Farkas K. (szerk.): Államigazgatás, terület- és településpolitika. Baranya Megyei Tanács, JPTE, Pécs, 65-82.

Faluvégi A. (2008): A foglalkoztatás területi-települési szerkezete Magyarországon. Statisztikai Szemle, 12., 1077-1102.

Fodor I., Hajdú Z. (szerk.) (1985): Szekszárd vonzáskörzetének vizsgálata. MTA RKK DTI, Pécs

Győri R. (2000): A Kisalföld kereskedelmi vonzáskörzet-rendszere 1925-ben. Tér és Társadalom, 2-3., 303-309.

Gyimesi S. (1975): A városok a feudalizmusba való átmenet időszakában. Akadémiai Kiadó, Budapest

Hajdú Z., T. Mérey K. (1985): A vonzáskörzet-kutatás történeti földrajzi kérdései. In: Faragó L., Hrubi L. (szerk.): A vonzáskörzetek gazdasági és közigazgatási kérdései. MTA RKK DTI, Pécs, 65-76. (MTA RKK DTI Közlemények; 32 .)

Hoggart, K. (2005): Convergence and Divergence in European City Hinterlands: A Cross-National Comparison. In: Hoggart, K. (ed.): The City's Hinterland: Dynamism and Divergence in Europe's PeriUrban Territories. Ashgate Publishing, Aldershot, 155-170.

Kertesi G. (2000): Ingázás a falusi Magyarországon - egy megoldatlan probléma. Közgazdasági Szemle, 10., 775-798.

Kleb B. (1978): Eger múltja a jelenben - a város alatti üregek településtörténeti és épitésföldtani vizsgálata. Budapesti Műszaki Egyetem, Budapest

Kovács T. (2002): Prológ a statisztikai kistérségi területbeosztás felülvizsgálatához. Területi Statisztika, 3., 203-209.

Kovács Z. (1986): Gyöngyös kiskereskedelmi vonzásterületének értékelése. Földrajzi Értesítő, 3-4., 339-351.

Kovács Z. (1987): Kereskedelmi centrumok és vonzáskörzetek Heves megyében. Földrajzi Értesíto”, 3-4., 253-272.

Kozma G. (2008): A dekoncentrált (területi) államigazgatási szervezetek központjainak változása 1990 után. Tér és Társadalom, 2., 71-85.

Köllő J. (1997): A napi ingázás feltételei és a helyi munkanélküliség Magyarországon. Esély: társadalom- és szociálpolitikai folyóirat, 2., 33-61.

McGrail, M. R., Humphreys, J. S. (2009): Measuring spatial accessibility to primary care in rural areas: Improving the effectiveness of the two-step floating catchment area method. Applied Geography, 29., 533-541. 
Mendöl T. (1963): Általános településföldrajz. Akadémia Kiadó, Budapest

Murphey, R. (1982): The scope of geography. Methuen \& Co., London, 28.

Nagy R. (1988): Szolnok város vonzásviszonyai (1949-1980). Alföldi Tanulmányok, 12., 219-236.

Papp A. (1981): Debrecen vonzáskörzete. Alföldi Tanulmányok, 5., 177-201.

Pearce, J. (2000): Techniques for defining school catchment areas for comparison with census data. Computers, Environment and Urban Systems, 24., 283-303.

Pénzes J. (2010): Területi jövedelmi folyamatok az észak-alföldi régióban a rendszerváltás után. Debreceni Egyetemi Kiadó, Debrecen (Studia Geographica 26.)

Pozder P. (1984): Eger vonzáskörzete. Egyetemi doktori értekezés, KLTE, Debrecen

Pozder P. (1985): Eger vonzáskörzete. KLTE Földrajzi Intézet, Debrecen (Studia Geographica, 5.)

Taylor, P. (2004): World city network: a global urban analysis. Routledge, London, 101-102.

Timár J. (1983): Vonzáskörzet-vizsgálatok Szarvas és Gyoma térségében. Alföldi Tanulmányok, 5., 231-254.

Timár, J., Kovács, Z. (2009): Hinterland development. In: Kitchin, R., Thrift, N. (eds.): International Encyclopedia of Human Geography. Elsevier Science, Oxford, 128-135.

Tóth J. (1977): Az Alföld intercentrális kapcsolatrendszere az interurbán telefonhívások alapján. Alföldi Tanulmányok, 1., 117-131.

Tóth G. (2005): Az autópályák szerepe a regionális folyamatokban. Központi Statisztikai Hivatal, Budapest

Vadász I. (1981): Tiszafüred vonzáskörzete. KLTE Földrajzi Intézet, Debrecen (Studia Geographica 4.) 